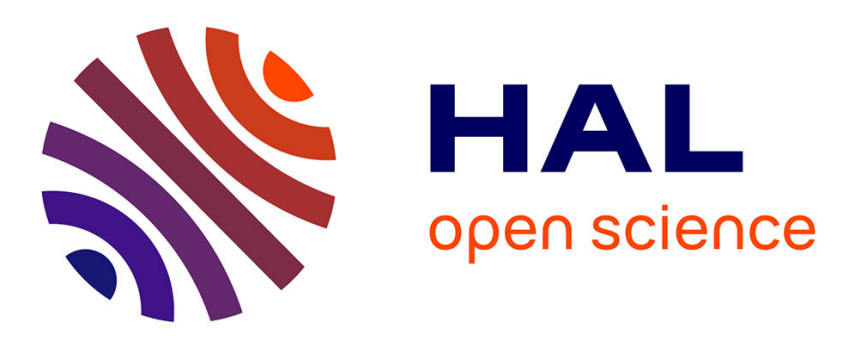

\title{
Solvent effects on the vibrational spectrum of 3-hydroxyflavone
}

Ari Paavo Seitsonen, Abdenacer Idrissi, Stefano Protti, Alberto Mezzetti

\section{To cite this version:}

Ari Paavo Seitsonen, Abdenacer Idrissi, Stefano Protti, Alberto Mezzetti. Solvent effects on the vibrational spectrum of 3-hydroxyflavone. Journal of Molecular Liquids, 2019, 275, pp.723-728. 10.1016/j.molliq.2018.11.020 . hal-02404703

\section{HAL Id: hal-02404703 https://hal.sorbonne-universite.fr/hal-02404703}

Submitted on 11 Dec 2019

HAL is a multi-disciplinary open access archive for the deposit and dissemination of scientific research documents, whether they are published or not. The documents may come from teaching and research institutions in France or abroad, or from public or private research centers.
L'archive ouverte pluridisciplinaire HAL, est destinée au dépôt et à la diffusion de documents scientifiques de niveau recherche, publiés ou non, émanant des établissements d'enseignement et de recherche français ou étrangers, des laboratoires publics ou privés. 


\title{
Solvent effects on the vibrational spectrum of 3-hydroxyflavone
}

Ari Paavo Seitsonen ${ }^{1,2,3, *}$, Abdenacer Idrissi, ${ }^{4}$ Stefano Protti, ${ }^{5}$ Alberto Mezzetti ${ }^{6, *}$

${ }^{1}$ Institut für Chemie, Universität Zürich, Winterthurerstrasse 190, CH-8057 Zürich

${ }^{2}$ Département de Chimie, Ecole Normale Supérieure, 24 rue Lhomond, F-75005 Paris

${ }^{3}$ Sorbonne Université et Centre National du Recherche Scientifique (CNRS), F-75005 Paris

${ }^{4}$ LASIR UMR 8516, Université de Sciences et Technologies de Lille, Bat C5, Cité Scientifique, F-59655 Villeneuve d'Ascq cedex, France

${ }^{5}$ PhotoGreen Lab, Department of Chemistry, University of Pavia, Viale Taramelli 10, I27100, Pavia, Italy

${ }^{6}$ Laboratoire de Réactivité de Surface UMR CNRS 7197, Sorbonne Université, 4 place Jussieu, F-75005 Paris, France

\begin{abstract}
3-hydroxyflavone (3HF) is a widely studied molecule that acts as a simplified prototype of biological, more complex flavonoids. Its solvation mechanism is still under investigation. Here we report a joint experimental and simulation study of the vibrational properties of $3 \mathrm{HF}$ in gas phase and in simple liquids tetrachloromethane, chloroform and acetonitrile using infra-red (IR) and Raman spectroscopies. We find reasonably good agreement between the static and molecular dynamics simulations employing density functional theory at the level of generalised gradient approximation (GGA) and hybrid functionals, but the agreement with the experimental spectra is only reasonable in the case of the IR spectroscopy and relatively poor in the case of Raman spectroscopy. The results can, however, be used as a starting point for discussing the solvation behaviour of the flavonoids.
\end{abstract}

\section{Introduction}

Flavonoids are natural compounds present in plants that exhibit several interesting biological properties, including, among others, radical scavenging ability [1], anti-carcinogenic [2] and antiproliferative [3]. Flavonols is a subclass of flavonoids which contain a 3hydroxypyran-4-one ring. The chemical basis of their anti-oxidant properties have been the object of extensive research [4;5 and refs therein]; in particular it has been found that the (micro)environment surrounding flavonols play a key role in modulating their reactivity [4; 6; 7; 8]. Interestingly, flavonol interactions with the surrounding environment deeply influence 
their photophysics; for this reason, they are also widely used as fluorescent probes [9; 10]. Whereas intermolecular hydrogen bonding interactions determines flavonol emitting properties, environment-induced deprotonation of $\mathrm{OH}$ group leads to formation of anions whose fluorescence spectrum (band shape, color, intensity etc) is different from the neutral molecule $[9 ; 11 ; 12]$.

Vibrational spectroscopy is a powerful approach to study the interaction between organic molecules and their surrounding environment, in particular proteins, at the atomic level. Vibrational spectroscopy can provide detailed information on pigment-protein / ligand-protein / cofactor-protein interactions, mechanism of ligand binding, mechanism of biochemical reactions etc [13]. Several vibrational spectroscopy techniques are widely applied in molecular biophysics to investigate these issues, such as resonant Raman spectroscopy [14], non-resonant Raman difference spectroscopy [15] and Fourier transform infra-red (FTIR) difference spectroscopy [16]. In these techniques, especially Resonance Raman, spectral contributions arising from the organic molecule can be identified, providing specific information on its interaction with the protein [14]. Molecular vibrations are sensitive to structure and intermolecular interactions (local dielectric constant, presence of hydrogen bonds etc); some vibrational marker bands are extremely sensitive probes [13]. A prerequisite to rationalise how the position of a vibrational band is influenced by the surrounding environment, is the detailed characterisation of the organic molecule in prototypical environments. To this aim organic solvents, which are characterised by precise physico-chemical parameters, are widely used. Experimental data on organic solvents can be fully exploited when calculations are used to assign vibrational modes or to rationalise solute-solvent interactions. Different approaches are used, such as density functional theory (DFT)-based calculations with an implicit solvent (see for instance [17]), DFT-based calculations with explicit solvent molecules (see for instance [18]) or QM/MM calculations (see for instance [19]).

In the last decade, a large number of studies have been carried out using vibrational spectroscopy to study flavonols in different microenvironments, eg. binding sites of biomacromolecules (see [20;21;22] and refs. therein), organic nanoparticles [23], liposomes [24] have been published. Its use in the study of chemical reactivity of flavonols has also been reported (see for instance [17; 25]). Vibrational spectroscopy of flavonols has also been successfully applied to food [26] and wine analysis [27]. Despite these efforts a clear interpretation the effect of the environment - through intermolecular interactions - on the position of the vibrational bands of flavonols is still lacking. 

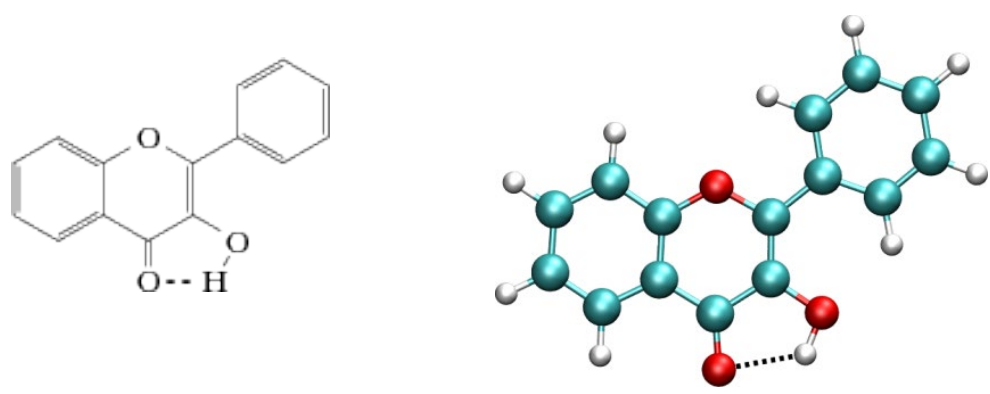

Scheme 1 Chemical structure of 3-hydroxyflavone (3HF)

Raman and IR spectra of the simplest among flavonols, 3-hydroxyflavone (3HF), have been used to investigate its interactions with several environments, such as glassy matrices [28], polysiloxanes [29] or zeolites [30]. There is further interest in the study of the interactions between $3 \mathrm{HF}$ and its environment due to its dual fluorescence [31], ie. from its normal state $\mathrm{N}^{*}$, and from its tautomeric state $\mathrm{T}^{*}$, where the proton - after an excited-state intramolecular proton transfer (ESIPT) reaction - is localised on the carbonyl oxygen. The efficiency and speed of ESIPT (and, as a consequence, on the relative intensity of the $\mathrm{N}^{*}$ and $\mathrm{T}^{*}$ fluorescence bands) depend strongly on the hydrogen bond (HB) interactions of $3 \mathrm{HF}$ with its environment [32]. In addition, as mentioned above, environment-induced deprotonation of the $\mathrm{OH}$ group of $3 \mathrm{HF}$ can occur, leading to anion formation with a completely different fluorescence spectrum $([33 ; 34]$ and refs. therein). Also the reactivity of 3HF [4;35] and photochemistry ([36] and refs. therein) are strongly solvent-dependent. Static and time-resolved vibrational spectroscopy have been used to follow and/or rationalise 3HF photophysics [37] and irreversible photochemistry in solution $[38 ; 39 ; 40]$, including the effect of the solvent on reaction mechanism.

The vibrational properties of $3 \mathrm{HF}$ have been the subject of several studies, with contrasting results: IR spectra were obtained in solid-state ([41] and refs. therein), in gas-phase [42; 43], in Ar matrices at 10 and $12 \mathrm{~K}$ [44; 45], in jet-cooled $3 \mathrm{HF}-\left(\mathrm{H}_{2} \mathrm{O}\right)_{\mathrm{n}}$ clusters [46], and in solvents [37; 47; 48]. Raman spectra were recorded in various solutions [40; 48; 49], and SERS in water solutions [41] and resonance Raman spectrum of 3HF in 3-methyl-pentane (cited in [44]) were also reported. Calculations of IR and Raman spectra of 3HF have been reported, using the AM1 method [49] or the DFT approach [40-44]. Nevertheless, some discrepancies have been reported in precise band assignments.

In this Article, we present Raman spectra of 3HF in three solvents: tetrachloromethane $\left(\mathrm{CCl}_{4}\right)$, chloroform $\left(\mathrm{CHCl}_{3}\right)$ and acetonitrile $(\mathrm{ACN})$. These were chosen because they range from apolar to polar, are all aprotic yet they impose a very different dielectric environment on 
the $3 \mathrm{HF}$, and they do not form (strong) hydrogen bonds with the solute, so as to avoid complications due to varying coordination of hydrogen bonds. We couple the present and former experimental findings with DFT simulations with an implicit solvent, in order to better understand the solvent effects on the main vibrational bands. In addition, in order to shed light on band attribution, we have simulated the IR spectrum of $3 \mathrm{HF}$ in gas phase and simple explicit solvent by a dynamical computational approach, relying on Car-Parrinello molecular dynamics analysis of $3 \mathrm{HF}$ in vacuum, and we compare the results to those obtained for $3 \mathrm{HF}$ in the gas phase [42].

\section{Methods}

\section{Experiments}

3HF was purchased from Aldrich, and re-crystallised from cyclohexane before use. Solvents were of spectroscopic grade. FT-Raman spectra were recorded on a Bruker IFS $66 \mathrm{~V}$ spectrometer. $1064 \mathrm{~nm}$ radiation from a Nd:YAG laser was used for excitation. In order to obtain spectra with a high signal to noise ratio 10000-40000 scans, depending on the solvent, were averaged. Spectra of pure solvents, obtained under the same conditions, were subtracted. Spectral resolution was $4 \mathrm{~cm}^{-1}$. Concentration was $500 \mathrm{ppm}\left(2,1 * 10^{-3} \mathrm{M}\right)$ for all samples. A preliminary set of Raman experiments $\left(\lambda_{\text {exc }}=632 \mathrm{~nm}\right)$ was carried out at lower concentrations (down to $1 * 10^{-3} \mathrm{M}$ ) showing the same spectral features, ensuring thereby the absence of solutesolute interactions. This is also in line with a series of UV-Vis spectra of $3 \mathrm{HF}$ in the three considered solvents, showing the same spectral features in the concentration range $5 * 10^{-5}$ $3 * 10^{-3} \mathrm{M}$ (results not shown), in agreement with a previous report [48].

\section{Calculations}

We performed the dynamical DFT simulations using the QuickStep module [50] of the CP2K package [https://www.CP2K.org/]. We employed the generalised gradient approximation BLYP [51; 52] to the exchange-correlation functional is the Kohn-Sham equations, and the DFT+D3 dispersion correction in order to be consistent with simulations where an explicit solvent molecules might be used. We used the TZV2P-GTH Gaussian basis set for the orbitals and a plane wave basis set up to a cut-off energy of 400 Ry for density together with Goedecker-Teter-Hutter pseudo potentials [53] in the Gaussian plane wave (GPW) scheme [54]. We ran Born-Oppenheimer molecular dynamics with a time step of $0.5 \mathrm{fs}$ 
in a canonical ensemble, where the average temperature was kept at $298.15 \mathrm{~K}$ using a thermostat chain. 35 ps of trajectory was considered in the analysis, and the initial trajectory of 94 ps with the smaller basis set TZVP-GTH was discarded. A similar molecular dynamics run was also performed on the explicitly solvated $3 \mathrm{HF}$ in $\mathrm{CCl}_{4}$ and $\mathrm{ACN}$, with trajectories of at least $50 \mathrm{ps}$ and the first 15 ps neglected. 128 solvent molecules were included in the simulation cell [55].

The static calculations with and without the implicit solvent were performed with the code TurboMole [56] within the harmonic analysis of the vibrations. We used the same $\mathrm{BLYP}+\mathrm{D} 3$ approach as in the dynamical simulations together with simulations employing the B3LYP hybrid functional [57] with the D3 term added, and def2-TZVPP basis sets. The model for the implicit solvent was COSMO [58].

The infra-red (IR) spectra from the static calculations were simulated by Gaussian broadening at the calculated harmonic frequencies $\omega_{i}$, marked in the graphs with circles. The IR intensity is calculated from the change in the dipole moment $D$ along a displacement $\Delta_{i}$ the corresponding normal mode $i, I_{I R} \propto \sum_{i}\left|\partial D / \partial \Delta_{i}\right| \delta\left(\omega-\omega_{i}\right)$. Similarly the Raman intensity is evaluated from the differential of the polarisability along each normal mode.

\section{Results}

\section{Vibrations in gas phase (isolated molecule)}

We start by discussing the results in the gas phase, or isolated, molecule. In Figure 1 we have the computed IR and isotropic Raman spectra both from the dynamical and static calculations, the latter broadened by convoluting with a Gaussian function. Overall the agreement is very good, with an additional shoulder in the dynamical spectrum of IR at about $1585 \mathrm{~cm}^{-1}$. In the spectra the strongest intensity is at around $1630 \mathrm{~cm}^{-1}$. This feature is redshifted in the dynamical simulations, most likely due to anharmonic effects that are not included in the static approach. The two methods yield similar spectra, so in the following we assume that the harmonic, static approach works relatively well.

[Figure 1 comes here] 


\section{Solvated $3 H F$}

Next we discuss the experimental and calculated harmonic, static IR and Raman spectra in the gas-phase molecule and the simple solvents $\mathrm{CCl}_{4}, \mathrm{CHCl}_{3}$ and $\mathrm{ACN}$. In the calculations we used both BLYP+D3 and B3LYP+D3 approaches to the exchange-correlation term, and in the simulation of solvated $3 \mathrm{HF}$ the implicit solvent. The results in Figure 2 require a careful analysis as the errors in the calculated spectra do not allow a straightforward assignment of the computed bands to the experimental peaks. We have fitted the scaling value of the computed frequencies so that best overall agreement is obtained between the experimental peak positions and computed frequencies leading to a value of 1.040 with BLYP+D3 and 0.991 with B3LYP+D3. Both the unscaled and scaled Frequencies are shown in Table 1. There are clear discrepancies between the calculated and measured spectra in the peak positions and the intensities. For example in the infra-red spectrum in ACN the calculated frequency of the highest-intensity peak is underestimated. In the FT-Raman spectra only one peak or frequency appears in the simulations at $1560-1610 \mathrm{~cm}^{-1}$, whereas two peaks are present in the experimental spectra, possibly reflecting two different situations (ie. solute-solvent interaction scenarios). In $\mathrm{ACN}$ the agreement in the position of the computational main peak is worse than in the other (implicit) solvents. This might be due to the complicated equilibrium of solute-solvent HBs of $3 \mathrm{HF}$ in $\mathrm{ACN}$, a solvent endowed with both hydrogen bond accepting basicity and also with some HB donating acidity. On the one hand, hydrogen bonding between the methyl group of $\mathrm{ACN}$ (HB donor) and the $\mathrm{O}_{\mathrm{CO}}$ is possible, but on the other hand the intra-molecular hydrogen bond can also be distorted if the $\mathrm{OH}$ group forms $\mathrm{HB}$ as a donor with the solvent molecules acting as acceptors via the nitrogen atom.

[Figure 2 comes here]

[Table 1 comes here]

We performed a further comparison between the dynamical and static calculations with experiments by also computing the IR spectrum in the explicit solvent. These results are collected into Figure 3. The statistics is quite poor in the case of $\mathrm{ACN}$, leading to very strong background signal, but we try to discern the signal from the weak maxima of the intensity. In the case of ACN we include also the experimental spectrum from Ref. [37], as this spectrum covers a wider spectral range than the spectra of solvated 3HF from Ref. [48]. This helps to compare the agreement of the lowest computational frequency at $\sim 1580 \mathrm{~cm}^{-1}$. Further experimental data are given in Table 2 as the peak positions. The harmonic, static and the 
dynamical simulation again agree well in the case of gas-phase $3 \mathrm{HF}$ and solvated in $\mathrm{CCl}_{4}$. In ACN the comparison is more difficult, possibly due to formation of hydrogen bonds between the solute and solvent molecules.

[Figure 3 comes here]

[Table 2 comes here]

In order to understand the character of the different vibrational modes we analysed the computational vibrational frequencies and the IR spectrum of two isotopically labelled 3HF molecules in gas phase with the harmonic-B3LYP+D3 approach, and from the dynamical properties of the $\mathrm{C}=\mathrm{O}$ unit in the $\mathrm{BLYP}+\mathrm{D} 3$ dynamical simulations. The latter were analysed using the Fourier transform of the bond length $\mathrm{C}=\mathrm{O}, d_{\mathrm{C}=\mathrm{O}}(t)$, shown in Figure 4 , and the Fourier transform of the auto-correlation function of the velocity of the $\mathrm{O}_{\mathrm{C}=\mathrm{O}}$. Thus the two quantities, results of which are given in Figure 5, indicate the contribution of the $\mathrm{C}=\mathrm{O}$ stretching vibration to the power spectrum at different frequencies.

[Figures 4 and 5 come here]

The isotopic substitution of the $\mathrm{H}_{\mathrm{OH}}$ to D leads to a large red shift of the highest frequency by about $10 \mathrm{~cm}^{-1}$, and smaller lowering of the second-highest frequency. Thus the highest frequency has a component on the $\mathrm{H}_{\mathrm{OH}}$. The replacement of the ${ }^{16} \mathrm{O}_{\mathrm{CO}}$ by ${ }^{18} \mathrm{O}_{\mathrm{CO}}$ leads to larger changes in the IR intensity and the frequencies. Again the highest frequency decreases, indicating a contribution on the $\mathrm{O}_{\mathrm{CO}}$. On the other hand the peak with the highest intensity is the third highest in the ${ }^{16} \mathrm{O}_{\mathrm{CO}}-3 \mathrm{HF}$, whereas in fourth highest in ${ }^{18} \mathrm{O}_{\mathrm{CO}}-3 \mathrm{HF}$. Thus also this peak has a large weight on the $\mathrm{O}_{\mathrm{CO}}$.

\section{Conclusions}

We have reported computer simulations and experiments on the vibrational properties of $3 \mathrm{HF}$ in the gas phase and in different organic solution. Nearly all 3HF vibrational bands have shown to be very sensitive to the surrounding solvent. Interestingly, the behaviour is not the same for all bands when moving from $3 \mathrm{HF}$ solution in the apolar $\mathrm{CCl}_{4}$ to the solution in the weakly polar $\mathrm{CHCl}_{3}$ and to the polar $\mathrm{ACN}$. This strongly suggests that specific solute-solvent interactions (hydrogen bonds) occur, especially in ACN. This is also the conclusion of a recent study based on UV-Vis and fluorescence spectroscopy in a large series of solvents, which 
underline that hydrogen bonds are relevant also in $\mathrm{ACN}$, an organic solvent normally considered as aprotic [59]. Possibly the partial disruption of the intramolecular HB in 3HF plays an important role in modifying spectral properties. The effect of isotope substitutions on calculated spectra suggests that it is very difficult to assign a given band to a single localised vibration (eg. $\mathrm{C}=\mathrm{O}$ stretching). A larger set of experimental vibrational data on isotopicallylabelled 3HF in several solvents is needed to better understand this issue.

\section{Acknowledgement}

We acknowledge Centre Régional Informatique et d'Applications Numériques de Normandie (CRIANN) for generous super-computing resources. 
[1] B.H. Havsteen, Pharmacol. Ther. 96 (2002) 67-202

[2] F.L. Juana, P.A.J. Angel, V.M. Manuel, in: R. Atta ur (ed)., Studies in Natural Products Chemistry, Elsevier (2012), pp. 115-134

[3] E. Middleton Jr, C. Kandaswami, T.C. Theoharides, Pharmacol. Rev. 52 (2000) 673-751

[4] M. Musialik, R. Kuzmicz, T.S. Pawlowski, G. Litwinienko, J. Org. Chem. 74 (2009) 2699-2709

[5] B. Butun, G. Topcu, T. Ozturk, Mini Rev Med Chem 18 (2018) 98-103

[6] M. Foti, G. Ruberto, G. J. Agric. Food Chem. 49 (2001) 342-348

[7] K. Sak, Mini Rev. Med. Chem. 14 (2014) 494-504

[8] C. Aliaga, M.C. Rezende, A. Arenas A, Food Chem. 113, (2009) 1083-87

[9] S. Protti, A. Mezzetti Photochemistry, 40 (2012) 295-322

[10] P.K. Sengupta, in Rev. Fluoresc. Geddes, C.D. (Ed), Springer UK 2016, pp. 45-70

[11] A. Mezzetti, S. Protti, C. Lapouge, J.P. Cornard, Phys. Chem. Chem. Phys. 13 (2011) 6858-6864

[12] S. Hofener, P.C. Kooijman, J. Groen, F. Ariese, L. Visscher Phys. Chem. Chem. Phys. 15 (2013) 12572-12581

[13] A. Barth, C. Zscherp, Q. Rev. Biophys. 35 (2002) 369-430

[14] B. Robert, Photosynth. Res. 101 (2009) 147-155

[15] R. Callender, H. Deng Ann. Rev. Biophys. Biomol. Struct. 23 (1994) 215-245

[16] A. Barth, Biochim. Biophys. Acta Bioenerg. 1767 (2007) 1073-1101

[17] Z. Jurasekova, C. Domingo, J.V. Garcia-Ramos, S. Sanchez-Cortes, Phys. Chem. Chem. Phys. 16 (2014) 12802-12811

[18] C. Marrassini, A. Idrissi, I. De Waele, K. Smail, N. Tchouar, M. Moreau, A. Mezzetti, J. Mol. Liq. 205 (2015) 2-8

[19] D. Bovi, A. Mezzetti, R. Vuilleumier, M.P. Gaigeot, B. Chazallon, R. Spezia, L. Guidoni, Phys. Chem. Chem. Phys. 13 (2011) 20954-64

[20] F.T. Liu, S.G. Agrawal, Z. Movasaghi, P.B. Wyatt, I.U. Rehman, J.G. Gribben, A.C. Newland, L. Jia, Blood 112 (2008) 3835-3846

[21] B. Sengupta, B. Pahari, L. Blackmon, P.K. Sengupta, Plos One 8 (2013) e65383

[22] S. Ionescu, I. Matei, C. Tablet, M. Hillebrand, Curr. Drug. Metab. 14 (2013) 474-490 
[23] A. Barras, A. Mezzetti, A. Richard, S. Lazzaroni, S. Roux, P. Melnyk, D. Betbeder, N. Montfillette-Dupont Int. J. Pharm. 379 (2009) 270-277

[24] M. Huang, E. Su, F. Zheng, C. Tan, Food Funct. 8 (2017) 3198-3208

[25] Z. Jurasekova, A. Torreggiani, M. Tamba, S. Sanchez-Cortes, J.V. Garcia Ramos, J. Mol. Struct. 918 (2009) 129-137

[26] O. Abbas, G. Compère, Y. Larondelle, D. Pompeu, H. Rogez, V. Baeten, Vibr. Spectr. 92 (2017) 111-118

[27] C.A. Teixeira dos Santos, R.N.M.J. Pascoa, J.A. Lopes, Trends Anal Chem. 88 (2017) $100-118$

[28] S. Protti, K. Raulin, O. Cristini, C. Kinowski, S. Turrell, A. Mezzetti, J. Mol. Struct. 993 (2011), 485-490

[29] M. Buffa, S Carturan, A. Quaranta, G. Maggioni, G. Della Mea, Opt. Mater. 34 (2012) $1219-1224$

[30] A. Moissette, M. Hureau, A. Kokaislova, A. Le Person, J.P. Cornard, I. De Waele, I. Batonneau-Gener, Phys. Chem. Chem. Phys. 17 (2015) 26207-26219

[31] P.K. Sengupta, M. Kasha, Chem Phys Lett 68 (1979) 382-5

[32] A.J.G. Strandjord, P.F. Barbara, J. Chem. Phys. 89 (1985) 2355-61

[33] S. Protti, A. Mezzetti, J.P. Cornard, C. Lapouge, M. Fagnoni, Chem Phys Lett 467 (2008) 88-93

[34] D. Loco, N. Gelfand, S. Jurinovich, S. Protti, A. Mezzetti, B. Mennucci, J. Phys. Chem A 122 (2018) 390-397

[35] S.L. Studer, W.E. Brewer, M.L. Martinez, P.-T. Chou, J. Am. Chem. Soc. 111 (1989) $7643-7644$

[36] S. Protti, A. Mezzetti, J. Mol. Liq. 205 (2015) 110-114

[37] K. Chevalier, M.M.N. Wolf, A. Funk, M. Andres, M. Gerhards, R. Diller, Phys. Chem. Chem. Phys. 14 (2012) 15007-15020

[38] P-T. Chou, S.L.Studer, M.L. Martinez, E. Orton, M. Young, Photochem. Photobiol. 53 (1991) 587-593

[39] M. Wang, T. Spataru, J.R. Lombardi, R.L. Birke, J. Phys. Chem. C.111 (2007) 30443052

[40] S Protti, A Mezzetti, C Lapouge, JP Cornard Photochem. Photobiol. Sci. 7 (2008) 109119 
[41] M. Wang,T. Teslova, F. Xu, T. Spataru, J.R. Lombardi, R.L. Birke, M. Leona, J. Phys. Chem. C 111 (2007) 3038-3043

[42] A. Vavra, R. Linder, K. Kleinermanns, Chem. Phys. Lett. 463 (2008) 349-352

[43] K. Bartl, A. Funk, K. Schwing, H. Fricke, G. Kock, H-D. Martin, M. Gerhards Phys. Chem. Chem. Phys. 11 (2009) 1173-1179

[44] J.M. Petroski, C. De Sa Valente, E.P. Kelson, S. Collins, J. Phys. Chem. A 106 (2002) 11714-11718

[45] W.E. Brewer, S. L. Studer, P T. Chou, Chem. Phys. Lett. 158 (1989) 345-350

[46] K. Bartl, A. Funk, M. Gerhards, J. Chem. Phys. 129 (2008) 234306

[47] N.A. Tyukavkina, N.N. Pogodaeva, E.I. Brodskaya, Y.M. Sapozhnikoy, Chem. Nat. Compd. 11 (1975) 613-616

[48] L. Vrielynck, PhD Thesis (1996) Université de Sciences et Technologies de Lille

[49] J.P. Cornard, L. Vrielynck, J.C. Merlin, J.C. Wallet Spectrochim. Acta. A. 51 (1995) 913-923

[50] J. VandeVondele, M. Krack, F. Mohamed, M. Parrinello, T. Chassaing, J. Hutter, Quickstep: Fast and accurate density functional calculations using a mixed Gaussian and plane waves approach, Comput. Phys. Commun. 167 (2005) 103

[51] A. D. Becke, Density-functional exchange-energy approximation with correct asymptotic behavior, Phys. Rev. A 38 (1988) 3098

[52] C. Lee, W. Yang, and R. G. Parr, Development of the Colle-Salvetti correlation-energy formula into a functional of the electron density, Phys. Rev. B 37 (1988) 785

[53] S. Goedecker, M. Teter, and J. Hutter, Separable dual-space Gaussian pseudopotentials, Phys. Rev. B 54 (1996) 1703

[54] G. Lippert, J. Hutter and M. Parrinello, The Gaussian and augmented-plane-wave density functional method for ab initio molecular dynamics simulations, Theor. Chem. Acc. 103 (1999) 124

[55] A. P. Seitsonen, A. Idrissi, S. Protti, A. Mezzetti, in preparation

[56] TURBOMOLE V7.1 2016, a development of University of Karlsruhe and Forschungszentrum Karlsruhe GmbH, 1989-2007, TURBOMOLE GmbH, since 2007; available from http://www.turbomole.com/

[57] P.J. Stephens, F. J. Devlin, C. F. Chabalowski and M. J. Frisch, Ab Initio Calculation of Vibrational Absorption and Circular Dichroism Spectra Using Density Functional Force Fields, J. Phys. Chem. 98 (1994) 11623-11627 
[58] A. Klamt; G. Schüürmann. COSMO: A new approach to dielectric screening in solvents with explicit expressions for the screening energy and its gradient. J. Chem. Soc. Perkin Trans. 2 (1993) 799-805. doi:10.1039/P29930000799

[59] S. Lazzaroni, D. Dondi, A. Mezzetti, S. Protti, Role of solute-solvent hydrogen bonds on the ground state and the excited state proton transfer in 3-hydroxyflavone. A systematic spectrophotometric study, Photochem. Photobiol. Sci. 17 (2018) 923-933.

doi:10.1039/C8PP00053K 
Table 1. The computed six vibrational frequencies of $3 \mathrm{HF}$ in different environments using an implicit solvent in the frequency range of interest here; both unscaled, $i e$ original, and scaled frequencies are shown 


\begin{tabular}{|c|c|c|c|c|c|c|c|}
\hline Method & & & & & & & \\
\hline Unscaled & & & & & & & \\
\hline Gas phase & $\begin{array}{l}\text { BLYP +D3 } \\
\text { B3LYP +D3 }\end{array}$ & $\begin{array}{l}1534 \\
1604\end{array}$ & $\begin{array}{l}1551 \\
1613\end{array}$ & $\begin{array}{l}1568 \\
1641\end{array}$ & $\begin{array}{l}1581 \\
1648\end{array}$ & $\begin{array}{l}1588 \\
1655\end{array}$ & $\begin{array}{l}1598 \\
1678\end{array}$ \\
\hline $\mathrm{CCl}_{4}$ & $\begin{array}{l}\text { BLYP +D3 } \\
\text { B3LYP +D3 }\end{array}$ & $\begin{array}{l}1529 \\
1601\end{array}$ & $\begin{array}{l}1550 \\
1613\end{array}$ & $\begin{array}{l}1559 \\
1635\end{array}$ & $\begin{array}{l}1579 \\
1643\end{array}$ & $\begin{array}{l}1588 \\
1655\end{array}$ & $\begin{array}{l}1592 \\
1668\end{array}$ \\
\hline $\mathrm{CHCl}_{3}$ & $\begin{array}{l}\text { BLYP +D3 } \\
\text { B3LYP +D3 }\end{array}$ & $\begin{array}{l}1524 \\
1598\end{array}$ & $\begin{array}{l}1551 \\
1613\end{array}$ & $\begin{array}{l}1555 \\
1631\end{array}$ & $\begin{array}{l}1577 \\
1642\end{array}$ & $\begin{array}{l}1588 \\
1654\end{array}$ & $\begin{array}{l}1590 \\
1664\end{array}$ \\
\hline $\mathrm{ACN}$ & $\begin{array}{l}\text { BLYP +D3 } \\
\text { B3LYP +D3 }\end{array}$ & $\begin{array}{l}1519 \\
1595\end{array}$ & $\begin{array}{l}1551 \\
1614\end{array}$ & $\begin{array}{l}1554 \\
1626\end{array}$ & $\begin{array}{l}1577 \\
1642\end{array}$ & $\begin{array}{l}1587 \\
1656\end{array}$ & $\begin{array}{l}1590 \\
1661\end{array}$ \\
\hline Scaled & & & & & & & \\
\hline Gas phase & $\begin{array}{l}\text { BLYP +D3 } \\
\text { B3LYP +D3 }\end{array}$ & $\begin{array}{l}1596 \\
1589\end{array}$ & $\begin{array}{l}1613 \\
1598\end{array}$ & $\begin{array}{l}1630 \\
1626\end{array}$ & $\begin{array}{l}1644 \\
1633\end{array}$ & $\begin{array}{l}1651 \\
1640\end{array}$ & $\begin{array}{l}1662 \\
1663\end{array}$ \\
\hline $\mathrm{CCl}_{4}$ & $\begin{array}{l}\text { BLYP +D3 } \\
\text { B3LYP +D3 }\end{array}$ & $\begin{array}{l}1590 \\
1587\end{array}$ & $\begin{array}{l}1612 \\
1598\end{array}$ & $\begin{array}{l}1621 \\
1620\end{array}$ & $\begin{array}{l}1642 \\
1628\end{array}$ & $\begin{array}{l}1652 \\
1640\end{array}$ & $\begin{array}{l}1656 \\
1653\end{array}$ \\
\hline $\mathrm{CHCl}_{3}$ & $\begin{array}{l}\text { BLYP +D3 } \\
\text { B3LYP +D3 }\end{array}$ & $\begin{array}{l}1585 \\
1583\end{array}$ & $\begin{array}{l}1613 \\
1599\end{array}$ & $\begin{array}{l}1618 \\
1616\end{array}$ & $\begin{array}{l}1640 \\
1628\end{array}$ & $\begin{array}{l}1651 \\
1640\end{array}$ & $\begin{array}{l}1654 \\
1649\end{array}$ \\
\hline$\overline{A C N}$ & $\begin{array}{l}\text { BLYP +D3 } \\
\text { B3LYP +D3 }\end{array}$ & $\begin{array}{l}1579 \\
1581\end{array}$ & $\begin{array}{l}1613 \\
1599\end{array}$ & $\begin{array}{l}1616 \\
1612\end{array}$ & $\begin{array}{l}1640 \\
1627\end{array}$ & $\begin{array}{l}1651 \\
1641\end{array}$ & $\begin{array}{l}1654 \\
1646\end{array}$ \\
\hline
\end{tabular}


Table 2. Experimental IR and Raman spectra of $3 \mathrm{HF}$ in different environments 


\begin{tabular}{|c|c|c|c|c|c|}
\hline $\begin{array}{l}\text { Normal mode } \\
\text { according to Ref } \\
\text { [39] }\end{array}$ & $\begin{array}{l}\text { C=O r stretch; } \\
\text { OH r bending; } \\
\text { C=C stretch }\end{array}$ & $\begin{array}{lr}\text { Ring B } & \text { quinoid } \\
\text { stretch; } & \text { OH } \\
\text { bend; } & \text { C=C } \\
\text { stretch } & \end{array}$ & $\begin{array}{l}\text { C=O } \quad \text { stretch; } \\
\text { C=C stretch }\end{array}$ & & $\begin{array}{l}\text { C=O r rtretch; } \\
\text { OH } \quad \text { bending; } \\
\text { C=C stretch }\end{array}$ \\
\hline \multicolumn{6}{|l|}{ IR Bands } \\
\hline Solid state [41] & $1562 s$ & $1602 s$ & 1610 & $1627 w$ & $1647 \mathrm{vw}$ \\
\hline $\begin{array}{l}\text { Ar } \quad \text { matrix } \\
10 \mathrm{~K}[44]\end{array}$ & & & & 1628 & $1652 w$ \\
\hline $\begin{array}{l}\mathrm{Ar} \quad \text { matrix } \\
12 \mathrm{~K}[45]\end{array}$ & 1578 & & $1618 \mathrm{sh}$ & 1630 & $1653 ; 1659$ sh \\
\hline gas phase [42] & 1570 & & 1618 & 1638 & (1656w) \\
\hline gas phase [43] & & & 1624 & 1630 & $1646 / 1653$ \\
\hline $\mathrm{CCl}_{4}[47]$ & & & 1622 & & 1652 \\
\hline $\mathrm{CCl}_{4}[48]$ & & & 1620 & & 1650 \\
\hline $\mathrm{CHCl}_{3}[48]$ & & & 1613 & & 1643 \\
\hline $\mathrm{CD}_{3} \mathrm{CN}$ [48] & & & 1620 & & 1641 \\
\hline \multicolumn{6}{|l|}{ Raman bands } \\
\hline Solid state [41] & $1566 \mathrm{vs}$ & 1594vs & 1619vs & & \\
\hline $\mathrm{CCl}_{4}$ [49] & & & & & 1648 \\
\hline МeOH [40] & 1569 & 1600 & 1614 & 1622 & \\
\hline $\begin{array}{l}\mathrm{MeOH} / \mathrm{H}_{2} \mathrm{O} \\
10 \%[40]\end{array}$ & 1566 & 1600 & 1614 & 1622 & \\
\hline $\begin{array}{l}\text { Nanoporous } \\
\mathrm{SiO}_{2}[28]\end{array}$ & $1568,1558 w$ & 1604 & 1615 & $1627 w ; 1639$ & 1651 \\
\hline $\begin{array}{l}\text { Methylpentane } \\
\text { Res Raman [44] }\end{array}$ & & & 1625 & & 1650 \\
\hline $\begin{array}{l}\mathrm{CCl}_{4} \\
\text { present work }\end{array}$ & 1574 & 1600 & 1620 & $1632 w$ & 1648 \\
\hline $\begin{array}{l}\mathrm{CHCl}_{3} \\
\text { present work }\end{array}$ & 1569 & 1599 & 1613 & & 1639 (broad) \\
\hline $\begin{array}{l}\mathrm{CH}_{3} \mathrm{CN} \text { present } \\
\text { work }\end{array}$ & 1571 & 1600 & 1621 & & 1639 (broad) \\
\hline $\begin{array}{|lr|}\text { Normal } & \text { mode } \\
\text { according } & \text { to } \\
{[39]} & \\
\end{array}$ & $\begin{array}{l}\mathrm{C}=\mathrm{O} \quad \text { stretch; } \\
\text { OH } \quad \text { bending; } \\
\mathrm{C}=\mathrm{C} \text { stretch }\end{array}$ & $\begin{array}{lr}\text { Ring B } & \text { quinoid } \\
\text { stretch; } & \text { OH } \\
\text { bend; } & \text { C=C } \\
\text { stretch } & \end{array}$ & $\begin{array}{l}\mathrm{C}=\mathrm{O} \quad \text { stretch; } \\
\mathrm{C}=\mathrm{C} \text { stretch }\end{array}$ & & 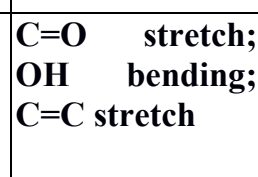 \\
\hline
\end{tabular}


Figure 1 Computed vibrational a) IR and b) Raman spectra of an isolated 3HF molecule from CPMD trajectories (solid lines) and harmonic analysis (dashed lines). 


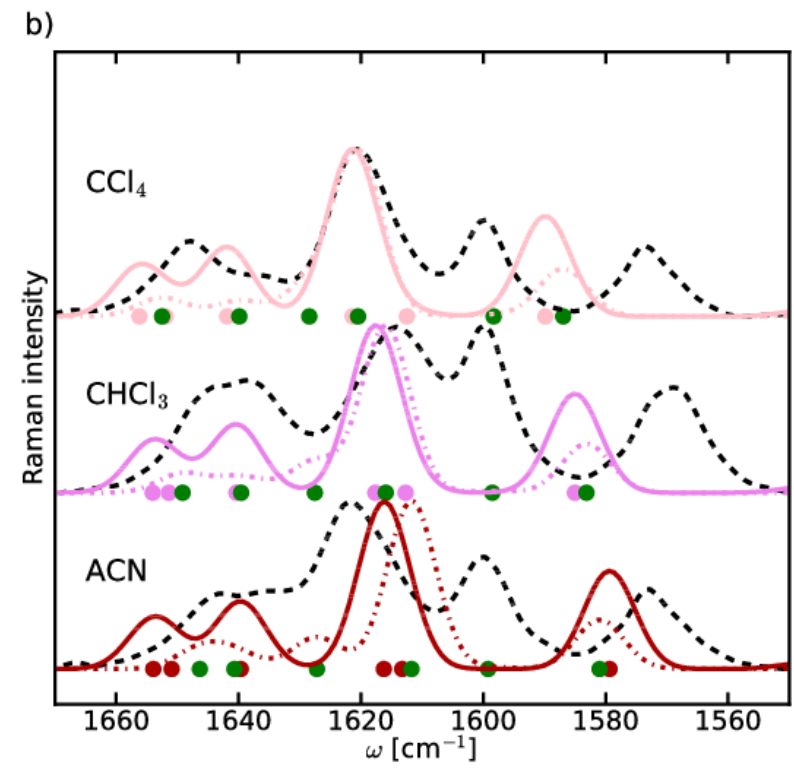

Figure 2 Experimental (black, dashed line) and simulated (BLYP+D3: solid lines and multiplecoloured circles; B3LYP+D3: dot-dashed lines and green circles) a) IR and b) Raman spectra of $3 \mathrm{HF}$ in gas phase (gp) and solvated in $\mathrm{CCl}_{4}, \mathrm{CHCl}_{3}$ and $\mathrm{ACN}$. The intensities of the gasphase calculations were used in Panel b). The experimental data are from Ref. [42] (IR, gasphase), Refs. [37,48] (IR, solvated) and present work (Raman). 
Figure 3 Experimental (black dashed lines) and simulated BLYP+D3 dynamical (solid lines) and harmonic (dot-dashed lines, circles) IR spectra. The dashed lines are from the experimental spectrum from Ref. [42] (gas-phase 3HF) and Ref. [48] (solvated 3HF) and the purple dotdashed line in ACN from Ref. [37]. 


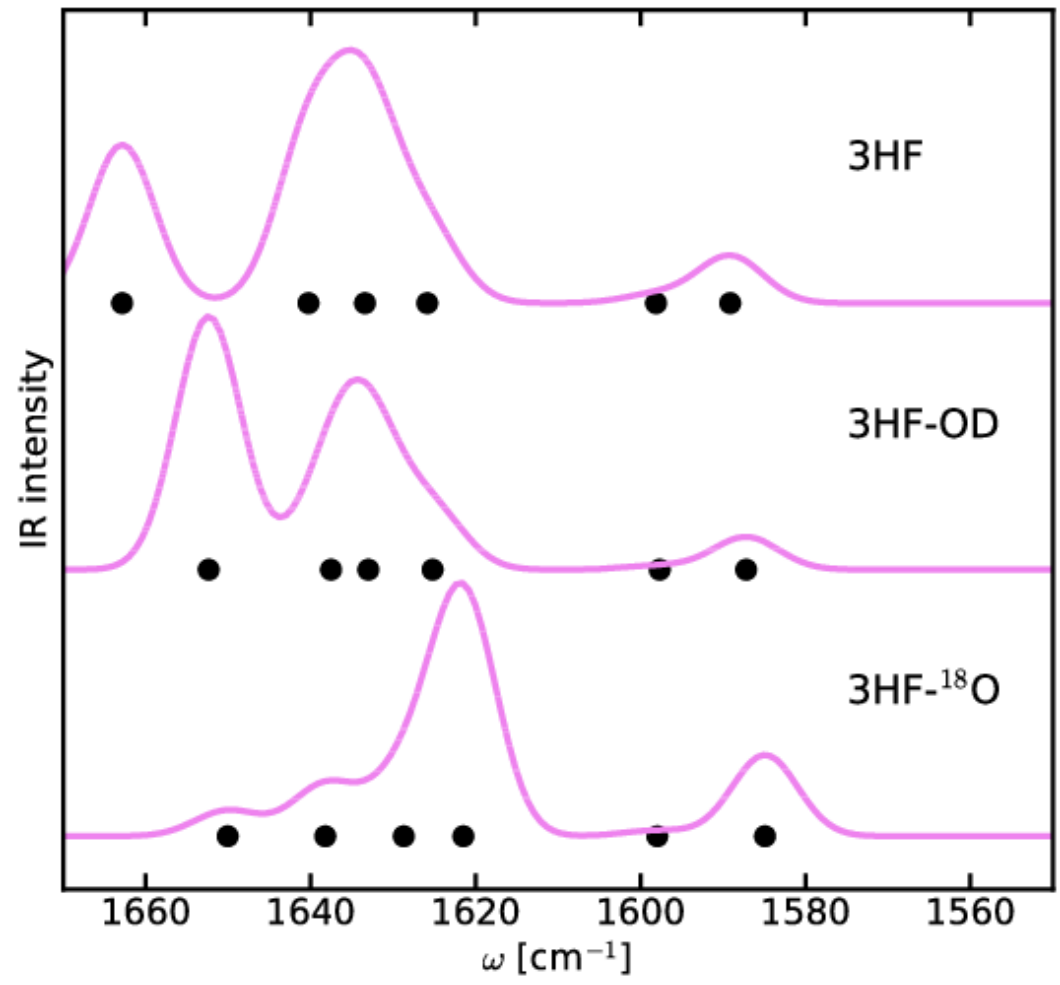

Figure 4 IR spectra of different isotopically-labelled 3HF in the gas phase calculated with the harmonic-B3LYP+D3 approach. 


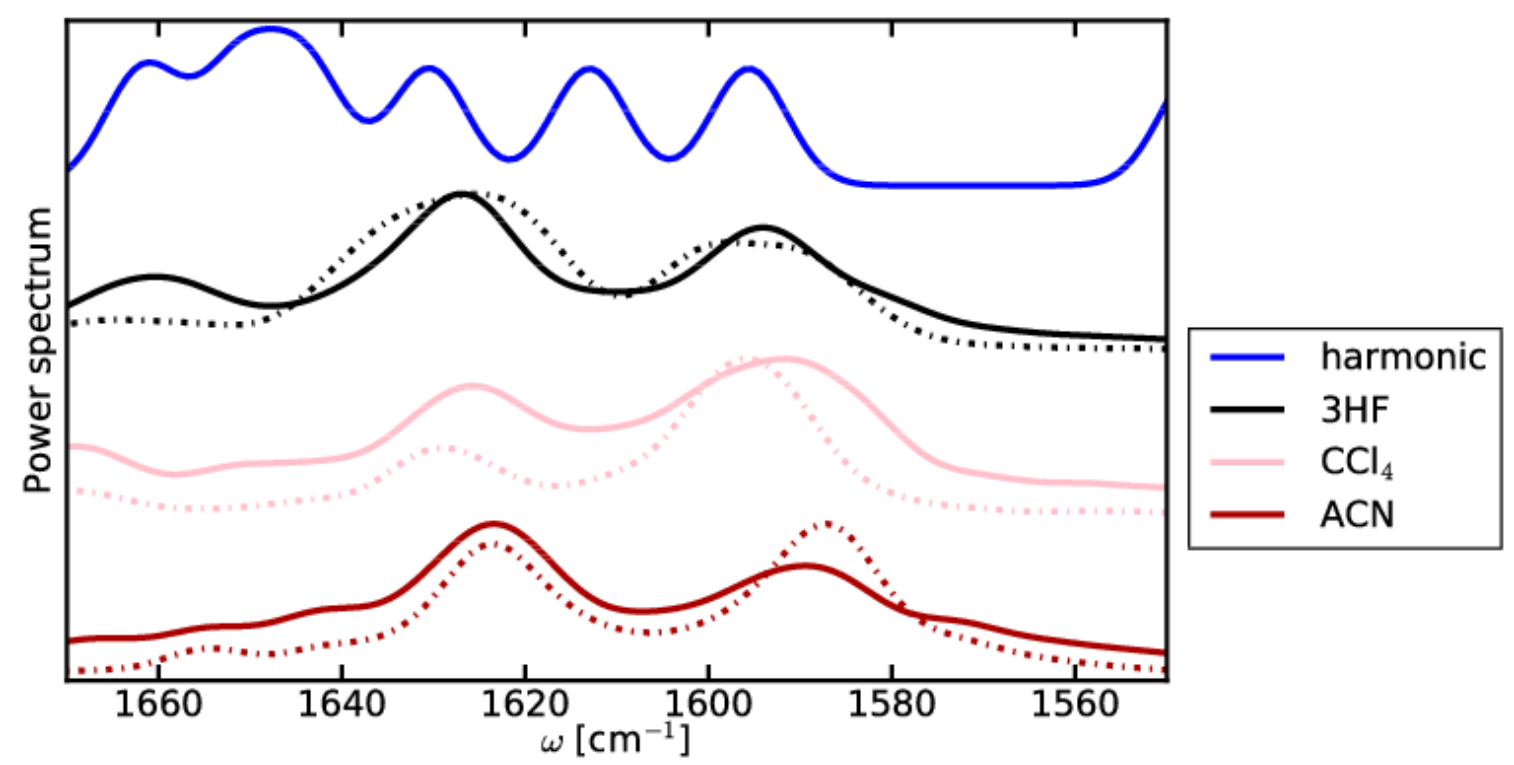

Figure 5 Power spectrum of the $\mathrm{C}=\mathrm{O}$ units from the Fourier transform of the $\mathrm{C}=\mathrm{O}$ bond (solid lines) and the auto-correlation function of velocity of the $\mathrm{O}_{\mathrm{CO}}$ (dashed lines) in different solvents from the dynamical simulations. The harmonic frequencies are given at the top. 